\title{
PENGELOLAAN ZAKAT PERTANIAN DI LAZIS NU KABUPATEN KENDAL
}

\author{
Abdul Hakim \\ UIN Walisongo Semarang \\ hakim_ibndjafar@yahoo.co.id
}

In Kendal, at least three social religious institutions that have influence in the community of Kendal, Nahdlatul Ulama (NU), Muhammadiyah, and Rifaiyyah.. Among the three institutions, Nahdlatul Ulama (NU) has the most members spread across the region Kendal, particularly among the farming community. Ideally, NU was able to encourage its members to carry out agricultural zakat. Especially in the NU Community has an institutions, LAZIS (Institution for Managerial Zakat and Shodaqoh). But in reality, of the amount of NU LAZIS scattered in the district of Kendal, only five LAZIS that optimally perform zakat empowerment of agriculture, namely District Rowosari, District Patebon, District Gemuh, District Kangkung, and District Boja. Its implementation is not maximized in the districts but still only focused on areas of the village or certain villages Management and organization become a serious problem in the utilization of zakat agriculture. Zakat management of agriculture focused on aspects of the collection and utilization. Organizational aspects can be solved by internal and external solutions through communication , mapping mustahik and internal consolidation with LAZIS - LAZIS NU in its territory .

Keywords : Management, Agricultural Zakat, LAZIS 


\section{A. Pendahuluan}

Zakat merupakan salah satu dari lima pilar yang menjadi tumpuan tegaknya Islam. Secara bahasa, zakat memiliki makna suci atau mensucikan. ${ }^{1}$ Menurut Qardawi arti dasar dari kata zakat ditinjau dari segi bahasa adalah suci, tumbuh, berkah, dan terpuji. ${ }^{2}$ Semuanya digunakan dalam Qur'an dan hadist. Tetapi yang terkuat, kata dasar Zaka berarti bertambah dan tumbuh. Sedangkan secara istilah, beberapa pendapat tokoh berkesimpulan pada pemaknaan zakat sebagai sejumlah harta tertentu yang diwajibkan oleh Allah untuk dikeluarkan dan diberikan kepada yang berhak menerimanya dengan persyaratan tertentu dengan harapan untuk mendapatkan berkah, membersihkan jiwa dan harta. ${ }^{3}$

Sedangkan pengertian zakat menurut istilah atau syara' yaitu: memberikan sebagian harta tertentu kepada yang berhak menerimanya dengan beberapa syarat. Jadi kalau kita tilik pula zakat menurut istilah agama Islam adalah kadar harta yang tertentu diberikan kepada yang berhak menerimanya dengan beberapa syarat yang tertentu. ${ }^{4}$ Meskipun para ulama didalam menafsirkannya berbeda-beda akan tetapi semuanya mengarah pada satu arti yaitu mengeluarkan sebagian harta benda untuk diberikan kepada fakir miskin sesuai dengan aturan-aturan yang telah ditentukan dalam al-Qur'an, sebagai pembersih serta penghapus kesalahan-kesalahan manusia. ${ }^{5}$

Syekh Husseinin Muhammad Makluf sebagaimana dikutip oleh Bakry mengemukakan bahwa harta benda yang diberikan kepada orang-orang fakir itu dinamakan zakat yang artinya perkembangan dan pembersihan, oleh karena mengeluarkan harta benda itu menyebabkan bertambah, berkembang dan memperbesar berkat kekayaan mereka, serta membersihkan dan penjagaan bagi orang yang memiliki kekayaan tadi dari bahaya dan kerugian yang menimpa kelak. $^{6}$

Mazhab Maliki mendefinisikan zakat dengan mengeluarkan sebagian dari harta yang khusus yang telah mencapai nishab (batas kwantitas minimal yang mewajibkan zakat) kepada orangorang yang berhak menerimanya. Mazhab Hanafi mendefinisikan zakat dengan menjadikan sebagian harta yang khusus dari harta yang khusus sebagai milik orang yang khusus, yang

1 Ahmad Warson Munawir, Kamus Al Munawir Arab-Indonesia Terlengkap, Surabaya: Pustaka Progresif, 1997, hlm. 557.

M. Syukri Ghazali, dkk., Pedoman Zakat 9 Seri, Jakarta: Proyek Peningkatan Sarana Keagamaan Islam, Zakat, dan Wakaf, 2001, hlm. 107

Al-Furqan Hasbi, 125 Masalah Zakat, Solo: Tiga Serangkai, 2008, hlm. 13

Muhammad Hasbi Ash Shiddiqy, Pedoman Zakat, Semarang: PT. Pustaka Rizki Putra, Cet. ke-10, 2006, hlm. 3

2 Yusuf Qardawi, Fiqhus Zakat, Terj. Salman Harun, et.al., Hukum Zakat, Bogor: Pustaka Litera Antar Nusa, Cet. ke-10, 2007, hlm. 74

3 Didin Hafidhuddin, Panduan Praktis tentang Zakat, Infak, Sedekah, Jakarta: Gema Insani, 1998, hlm. 13

B. Wiwoho, dkk (editor), Zakat dan Pajak, Jakarta: Bina Rena Pariwara, 1994, hlm. 32

4 Nazar Bakry, Problematika Figh Islam, Jakarta: PT Raja Grafindo Persada, Cet. ke-1, 1994., hlm. 29.

5 Sudarsono, Sepuluh Aspek Agama Islam, Jakarta: PT Rineka Cipta, Cet. ke-1, 1994, hlm. 73.

6 Nazar Bakry,Problematika Fiqh Islam, hlm. 33 
ditentukan oleh syari'at karena Allah. Mazhab Syafi'i, zakat merupakan sebuah ungkapan keluarnya harta sesuai dengan cara khusus. Sedangkan menurut mazhab Hambali, zakat ialah hak yang wajib dikeluarkan dari harta yang khusus untuk kelompok yang khusus pula.?

Para pemikir ekonomi Islam kontemporer mendefinisikan zakat sebagai harta yang telah ditetapkan oleh pemerintah atau pejabat berwenang kepada masyarakat umum atau individu yang bersifat mengikat dan final, tanpa mendapat imbalan tertentu yang dilakukan pemerintah sesuai dengan kemampuan pemilik harta, yang dialokasikan untuk memenuhi kebutuhan delapan golongan yang telah ditentukan dalam al-Qur'an, serta untuk memenuhi tuntutan politik bagi keuangan Islam. ${ }^{8}$

Meskipun para ulama mengemukakannya dengan redaksi yang agak berbeda antara satu dan yang lainnya, akan tetapi pada prinsipnya sama, yaitu bahwa zakat itu adalah bagian dari harta dengan persyaratan tertentu, yang Allah SWT mewajibkan kepada pemiliknya untuk diserahkan kepada yang berhak menerimanya dengan persyaratan tertentu pula. ${ }^{9}$ Hal tersebut senada dengan pasal 1 ayat (2) Undang-undang Republik Indonesia No 38 Tahun 1999 Tentang Pengelolaan Zakat yaitu: Zakat adalah harta yang wajib disisihkan oleh seorang muslim atau badan yang dimiliki oleh seorang muslim sesuai dengan ketentuan agama untuk diberikan kepada yang berhak menerimanya. ${ }^{10}$

Dengan demikian dapat dimengerti bahwasanya zakat memiliki dua nilai fungsi. Nilai fungsi yang pertama berkaitan dengan orang yang mengeluarkan zakat, yakni zakat berfungsi untuk membersihkan jiwa dan harta benda muzakki. Sedangkan fungsi kedua adalah berkaitan dengan orang yang menerima zakat tersebut. Fungsi ini berkaitan dengan upaya peningkatan kesejahteraan dan wujud prinsip ta’awun dalam ajaran Islam.

Penjelasan di atas, selain berkesimpulan tentang fungsi zakat juga terkandung penjelasan tentang orang-orang tertentu yang memiliki hak untuk menerima zakat. Dalam ajaran Islam, orang-orang yang berhak menerima zakat disebut dengan istilah mustahik zakat. Ada delapan kelompok yang menjadi mustahik zakat dalam Islam. Kedelapan kelompok tersebut adalah fakir, miskin, mualaf, sabilillah, ibnu sabil, gharim, untuk (membebaskan) hamba sahaya, dan amil . ${ }^{11}$ Hal ini sebagaimana dijelaskan oleh Allah dalam at-Taubah : 60.12

Zakat diwajibkan atas orang Islam yang mempunyai kekayaan yang cukup nishab, yaitu jumlah minimal harta yang wajib dikeluarkan zakatnya. Jika kurang dari itu kekayaan belum dikenai zakat. Adapun saat haul ialah waktu wajib mengeluarkan zakat yang telah memenuhi

7 Wahbah al-Zuhayliy, Al-Fiqh al-Islami Wa 'Adilla,Terj. Agus Efendi dan Bahrudin Fanani "Zakat Kajian Berbagai Mazhab", Bandung: PT. Remaja Rosda Karya, Cet. ke-1, 2000, hlm. 83.

8 Ali Nuruddin, Zakat sebagai Instrumen Kebijakan Fiskal, Jakarta: PT. Raja Grafindo Persada, Cet. ke-1, 2006., hlm. 7.

9 Didin Hafidhuddin, Panduan Praktis tentang Zakat, Infak, Sedekah, hlm. 9.

10 Saifudin Zuhri, Zakat Kontekstual, Semarang: CV Bima Sejati, Cet. ke-1, 2000., hlm. 81.

11 Muhammad al-Utsaimin, bin Shalih, Fatwa-Fatwa Zakat Edisi Lengkap, terj. Suharlan, dkk., Jakarta: Darus Sunnah, 2008, hlm. 209-210. Lihat Yusuf Qardawi, Fiqhus Zakat, Terj. Salman Harun, et.al., Hukum Zakat, hlm. 921.

12 Departemen Agama RI, Al Qur'an dan Terjemahnya. Bandung. 2005, hlm. 288 
nishabnya (dimiliki cukup dalam waktu setahun). ${ }^{13}$

Di dalam al-Qur'an, Allah SWT telah menyebutkan tentang zakat dan shalat sejumlah 82 ayat. Dari sini dapat disimpulkan secara deduktif bahwa setelah shalat, zakat merupakan rukun Islam terpenting. ${ }^{14}$ Zakat dan shalat dalam al-Qur'an dan al-Hadist dijadikan sebagai perlambang keseluruhan ajaran Islam. Pelaksanaan shalat melambangkan baiknya hubungan seorang dengan Tuhannya, sedang zakat adalah lambang harmonisnya hubungan antara sesama manusia. Oleh karena itu zakat dan shalat merupakan pilar-pilar berdirinya bangunan Islam. Jika keduanya hancur, Islam sulit untuk bertahan.

Zakat menjadi dua jenis, yakni zakat fitrah dan zakat mal. Zakat fitrah kata fitri berasal dari kata dasar (فطر) yang berarti membuat, menciptakan, menimbulkan, berbuka, makan pagi. ${ }^{15}$ Menurut para ahli fiqh, fitrah adalah tabiat yang suci dan asli yang dibawa manusia sejak lahir. ${ }^{16}$ Zakat fitrah juga disebut zakat badan atau zakat kepala atau zakat pribadi menurut para ahli fiqh. ${ }^{17}$ Imam Taqiyudin juga menyebutkan zakat fitrah dengan zakat badan: ${ }^{18}$

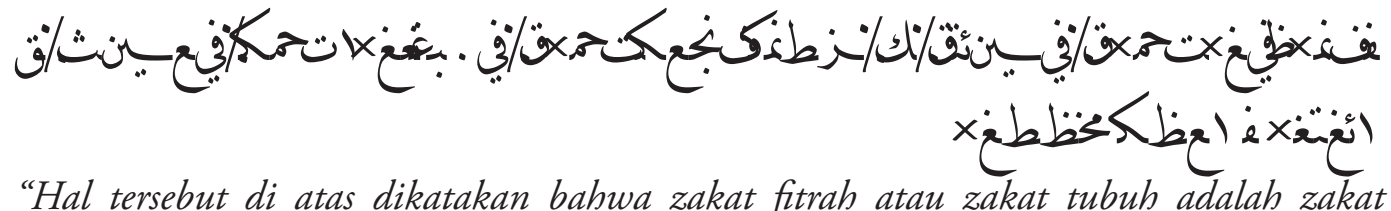

Artinya: "Hal tersebut di atas dikatakan bahwa zakat fitrah atau zakat tubuh adalah zakat badan karena zakat tersebut membersibkan diri atau jiwa atau mensucikannya dan meningkatkan derajat anaknya".

Jadi, zakat fitrah atau zakat badan adalah zakat yang wajib dibayarkan setiap muslim setelah bulan Ramadhan, baik laki-laki, wanita, dewasa maupun anak kecil, baik orang merdeka maupun hamba sahaya (budak) yang tujuannya untuk membersihkan dan mensucikan jiwa manusia. ${ }^{19}$

Pengertian zakat fitrah dalam UU RI No. 38 Tahun 1999 tentang Pengelolaan Zakat Pasal 11 ayat 1 adalah sejumlah bahan makanan pokok yang dikeluarkan pada bulan Ramadhan oleh setiap orang muslim bagi dirinya dan bagi orang yang ditanggungnya yang memiliki kelebihan makanan pokok untuk sehari pada hari raya Idhul fitri.

Sedangkan zakat mal merupakan zakat yang berhubungan dengan harta, yang dikeluarkan karena harta tersebut telah dimiliki penuh selama satu tahun (haul) dan memenuhi standar nisabnya (kadar minimum harta yang terkena zakat). Dalam terjamah Kifayat al-Ahyar harta yang wajib dizakati ada 5 macam, yaitu: ${ }^{20}$ Ternak; Perhiasan (Emas dan perak); Tanaman (hasil

13 Muhammad al-Utsaimin bin Shalih, Fatwa-Faywa Zakat Edisi Lengkap, hlm. 117.

14 Muhammad, Zakat Profesi: Wacana Pemikiran Dalam Figh Kontemporer, Jakarta: Salemba Diniyah, 2002, hlm. 12.

15 Atabik Ali, dan Ahmad Zuhdi Mudhor, Kamus Kontemporer Arab Indonesia, Yogyakarta: Multi karya Grafika, 2003, hlm. 1398.

16 Abdul Aziz Dahlan, (eds), Ensiklopedi Hukum Islam, Jilid 2, Cet-1, Jakarta: Ichtiar Baru Van Hoeve, 1996, hlm. 380 .

17 Yusuf Qardawi, Fiqhus Zakat, Terj. Salman Harun, et.al., Hukum Zakat, hlm. 921.

18 Imam Taqiyudin, Kifayat al-Ahyar, Dar al-Ihya' al-Kutub Arabiah, Juz-I, tth, hlm. 192.

19 Abdul Aziz Dahlan, (eds), Ensiklopedi Hukum Islam, Jilid 2, hlm. 391.

20 Moh Rifäi,. dkk, Tarjamah Khulasah Kifayatul Akhyar, Semarang; Toha Putra, 1978, hlm. 123. 
tanaman); Buah-buahan; dan Perniagaan.

Klasifikasi jenis zakat secara tidak langsung juga mengindikasikan adanya kewajiban zakat pada setiap matapencaharian masyarakat yang berhubungan dengan klasifikasi zakat mal di atas. Apabila klasifikasi zakat tersebut dilaksanakan di kalangan masyarakat Indonesia, maka kemungkinan besar akan diperoleh hasil pengumpulan zakat dalam jumlah besar. Namun sayangnya hal itu belum terlaksana secara menyeluruh. Masih banyak masyarakat Indonesia yang mempunyai mata pencaharian yang belum melaksanakan zakat sesuai dengan hasil mata pencaharian mereka. Salah satu contoh adalah di kalangan masyarakat petani, khususnya di kalangan masyarakat petani Kabupaten Kendal.

\section{B. Problematika Pengelolaan Zakat LAZIS NU di Kabupaten Kendal}

Kendal merupakan salah satu wilayah Pemerintahan Kabupaten yang ada di wilayah Pemerintahan Propinsi Jawa Tengah yang mayoritas mata pencaharian penduduknya adalah petani. Agama dominan masyarakat Kabupaten Kendal adalah Islam. Sebagai konsekuensi dari matapencaharian petani dan beragama Islam, idealnya di wilayah Kabupaten Kendal zakat pertanian dapat diterapkan. Namun kenyataannya zakat pertanian di wilayah Kabupaten Kendal belum terlaksana secara maksimal. Padahal jika melihat dari keberadaan kelembagaan agama yang ada di wilayah Kendal, juga akan menimbulkan pertanyaan mengapa implementasi zakat pertanian kurang bisa maksimal di wilayah Kabupaten Kendal.

Di wilayah Kabupaten Kendal paling tidak ada tiga lembaga keagamaan sosial yang memiliki pengaruh di lingkungan masyarakat Kabupaten Kendal. Ketiga lembaga keagamaan sosial tersebut adalah Nahdlatul Ulama (NU), Muhammadiyah, dan Rifaiyyah yang masingmasing lembaga tersebut memiliki anggota dalam jumlah yang tidak sedikit. Di antara ketiga lembaga tersebut, Nahdlatul Ulama (NU) paling banyak memiliki anggota yang tersebar di seluruh wilayah Kabupaten Kendal, khususnya di kalangan masyarakat petani. Idealnya, NU mampu mendorong para anggotanya untuk melaksanakan zakat pertanian. Terlebih di lingkungan lembaga NU juga ada Lembaga Amil Zakat Infaq dan Shadaqah (LAZIS).

Namun kenyataannya, dari jumlah LAZIS NU yang tersebar di wilayah Kabupaten Kendal, hanya ada lima LAZIS yang secara maksimal melakukan pemberdayaan zakat pertanian yakni Kecamatan Rowosari, Kecamatan Patebon, Kecamatan Gemuh, Kecamatan Kangkung, dan Kecamatan Boja. Pelaksanaannya juga belum maksimal dalam wilayah kecamatan namun masih hanya terpusat pada wilayah-wilayah kelurahan atau desa-desa tertentu. ${ }^{21}$

Fenomena di atas jika dikaji dalam konteks sosiologi hukum akan memunculkan persoalan seputar dimensi transformasi hukum Islam. Dimensi-dimensi hukum Islam sendiri terdiri dari tiga dimensi, yakni dimensi pemeliharaan, dimensi pembaharuan, dan dimensi penciptaan. ${ }^{22}$ Persoalan yang dimaksud adalah berhubungan dengan pemeliharaan pelaksanaan zakat pertanian yang telah terjadi perubahan dalam masyarakat yang berkaitan dengan hukum agama. Hal ini tentu memerlukan sebuah penyelesaian masalah yang utuh sehingga mampu mengembalikan

21 Nur Fathoni: wawancara, 2011

22 Lili Rasyidi, Filsafat Hukum Mazhab dan Refleksinya, Bandung: Remaja Rosdakarya, 1989., hlm. 144. 
hukum Islam kepada fungsinya. Menurut Donohue dan Esposito hukum Islam memiliki fungsi pengendali masyarakat, perekayasa sosial, dan pensejahtera masyarakat. ${ }^{23}$

Pengentasan kemiskinan merupakan salah satu masalah yang menjadi prioritas kerja dari Pemerintah Kabupaten Kendal. Namun jika dikembalikan pada pendayagunaan zakat produktif, dengan berpedoman pada bagian yang diberikan untuk zakat produktif, maka pembagian tersebut seakan sangat jauh dari prioritas kerja Pemkab Kendal.

Pada UU No. 38 Tahun 1999 tentang Pengelolaan Zakat, khususnya Pasal 16 ayat (2) yang menyebutkan "Pendayagunaan hasil pengumpulan zakat berdasarkan skala prioritas kebutuhan mustahik dan dapat dimanfaatkan untuk usaha yang produktif". Pasal tersebut paling tidak menjelaskan tentang dua hal penting dalam pendayagunaan zakat, termasuk zakat produktif. Kedua hal tersebut adalah: Pertama, berkaitan dengan skala kebutuhan mustahik yang dijadikan dasar pendayagunaan zakat yang mestinya harus disesuaikan dengan kebutuhan mustahik. Dalam hal ini, seyogyanya Pemerintah Kabupaten Kendal menyelaraskan pendayagunaan zakat dengan prioritas program kerja Pemkab Kendal.

Sesuai dengan kandungan pertama dalam Pasal 16 ayat (2) di atas, idealnya Pemkab Kendal memprioritaskan pendayagunaan zakat untuk modal produksi dari para mustahik. Hal ini berdasar pada prioritas kerja Pemkab Kendal dan fakta lapangan terkait dengan keadaan kesejahteraan penduduk Kabupaten Kendal. Menurut data statistik Pemkab Kendal, dari total Kepala Keluarga (KK) sebanyak 261.284 yang tersebar di 20 kecamatan, terdapat 115.629 KK (lebih dari 40\%) yang masih masuk dalam kategori keluarga pra sejahtera (Kendal, 2008: 112). Salah satu acuan untuk dapat menentukan tingkat kesejahteraan adalah dengan mengacu pada jenis rumah penduduk. Dari total 237.666 rumah penduduk yang terdata, lebih dari $50 \%$ merupakan bangunan yang tidak termasuk dalam kategori semi permanen atau bahkan permanen. Sebanyak 126.278 rumah penduduk masih terbuat dari kayu atau papan (101.189) dan bambu atau bahan lainnya (25.089) 24 .

Apabila pendayagunaan zakat dilakukan oleh LAZIS NU Cabang Kendal dengan mengacu pada prioritas kerja dan fakta lapangan, bisa jadi pembagian zakat tidak akan seperti yang telah dilaksanakan pada pendayagunaan zakat produktif periode 2008-2009. Namun di sisi lain, pendayagunaan zakat produktif yang dilakukan oleh tersebut masih mengacu pada pemerataan penerimaan di kalangan mustahik zakat. Hal inilah yang menjadi penyebab praktek pendayagunaan zakat produktif oleh LAZIS NU Cabang Kendal kurang sesuai dengan kandungan UU No. 38 Tahun 1999 tentang Pengelolaan Zakat, khususnya Pasal 6 ayat (2).

Kandungan kedua dalam Pasal 16 ayat (2) adalah terkait dengan kebolehan pendayagunaan zakat produktif sebagai zakat produktif (untuk modal usaha produktif) masyarakat Kabupaten Kendal. Memang dalam pelaksanaan pendayagunaan zakat produktif oleh LAZIS NU Cabang Kendal terdapat bagian zakat yang ditujukan untuk usaha produktif. Namun jika ditinjau

23 John Donohue, dan John L. Esposito, Pembaharuan Pemikiran dalam Islam, Jakarta: Rajawali, 1984., hlm. 72.

24 Kantor BPS Kabupaten Kendal, data dilihat pada tahun 2009-2011 
dari jumlah alokasi besarnya zakat serta penerima zakat, maka pendayagunaan tersebut belum maksimal dan sangat jauh dari pelaksanaan manfaat zakat dalam menunjang program kerja Pemkab Kabupaten Kendal.

Padahal jika melihat jumlah penduduk yang kurang sejahtera, maka pengambilan mustahik zakat yang menerima zakat produktif dari zakat produktif LAZIS NU Cabang Kendal dengan kuota satu kecamatan diwakili oleh dua orang kurang sesuai. Jumlah tersebut tentu sangat jauh dari jumlah masyarakat Kabupaten Kendal yang membutuhkan bantuan modal untuk usaha produktif.

Minimnya alokasi zakat produktif untuk usaha produktif lebih dikarenakan pendekatan yang dilakukan oleh LAZIS NU Cabang Kendal cenderung mengarah pada pendekatan parsial daripada pendekatan struktural. Pendekatan parsial merupakan pendekatan yang ditujukan kepada orang yang miskin dan lemah serta dilaksanakan secara langsung dan bersifat insidentil. Dengan cara ini masalah kemiskinan dapat diatasi untuk sementara. Sedangkan pendekatan secara struktural merupakan pendekatan yang lebih mengutamakan pemberian pertolongan secara berkesinambungan yang bertujuan agar mustahik zakat dapat mengatasi masalah kemiskinan dan diharapkan nantinya mereka menjadi muzaki. ${ }^{25}$

Memang dalam pelaporannya, LAZIS NU Cabang Kendal tidak menyebutkan secara detail fungsi alokasi zakat produktif kepada sabilillah. Untuk kelompok amil, fungsi alokasi zakat produktif sudah jelas, yakni bersifat konsumtif karena digunakan untuk keperluan konsumsi dan operasional para amil dalam mendistribusikan zakat produktif. Tidak adanya keterangan dalam pelaporan tersebut dapat memunculkan dua kemungkinan pemanfaatan zakat produktif yang diterima oleh kelompok sabilillah. Kemungkinan pertama, digunakan untuk memenuhi kebutuhan konsumsi (konsumtif), sedangkan kemungkinan kedua, digunakan untuk kebutuhan produktif.

Namun setelah ditelusuri lebih jauh, ternyata zakat yang diterima digunakan untuk kepentingan konsumtif. Penyebabnya tidak lain dikarenakan jumlah atau nominal yang diterima sedikit serta tidak adanya kepemilikan usaha yang produktif. Pendayagunaan zakat produktif yang cenderung bersifat konsumtif merupakan hal yang tidak efektif. Terlebih lagi pihak yang menerima zakat tersebut pada dasarnya memiliki kemampuan dalam memenuhi kebutuhan konsumtif mereka meskipun tidak memperoleh bagian dari pendayagunaan zakat, termasuk zakat produktif. Idealnya, bagian zakat yang diperuntukkan bagi sabilillah dapat dikurangkan atau dialihfungsikan untuk usaha produktif yang dapat menunjang pengembangan ekonomi.

Menurut Qodri Azizi, dana zakat akan lebih berdaya guna jika dikelola menjadi sumber dana yang penggunaannya sejak dari awal sebagai pelatihan atau untuk modal usaha dan hal ini diharapkan dapat mengentaskan seseorang dari kemiskinan. ${ }^{26}$ Pendistribusian zakat yang dilakukan oleh lembaga amil zakat tersebut dapat diarahkan pada program-program yang memberi manfaat jangka panjang untuk perbaikan kesejahteran mustahik menjadi muzaki,

25 Saifuddin Zuhri, 2000: 51

26 Qodri, Abdillah Azizy, Membangun Fondasi Ekonomi Umat : Meneropong ProspekBerkembangnya Ekonomi Islam, Yogyakarta: Pustaka Pelajar, 2004, hlm 149 
melalui peningkatan kualitas sumber daya manusia dan pemberdayaan sosial serta pengembangan ekonomi, seperti program pengembangan ekonomi umat, program beasiswa, program pelayanan sosial dan kemanusiaan, dan program dakwah masyarakat. ${ }^{27}$

Dari dua pendapat tersebut di atas, maka lebih baik pendayagunaan zakat produktif di wilayah LAZIS NU Cabang Kendal difokuskan pada pendekatan struktural yang cenderung produktif daripada dipusatkan pada pendekatan parsial yang cenderung konsumtif. Sebenarnya pendayagunaan zakat produktif untuk usaha produktif dapat diterapkan pada kelompok sabilillah. Cara yang dapat ditempuh misalnya adalah dengan mengaplikasikan dana penerimaan zakat tersebut untuk modal usaha bersama dari para "Guru Ngaji/Ustadz Kampung/Musholla" yang sebelumnya dikelompokkan terlebih dahulu sesuai dengan kedekatan wilayah kecamatannya. Jika hal ini dilaksanakan, maka dalam setiap kelompok "Guru Ngaji” yang terbentuk akan lahir sebuah usaha bersama berbasis ekonomi yang tentunya akan sangat membantu para "Guru Ngaji" dalam upaya pengembangan ekonomi mereka. Hal yang sama juga dapat diterapkan pada kelompok sabilillah. Adanya pengelompokkan beberapa panti asuhan maupun panti jompo dalam beberapa kelompok dan diberikan kepada masing-masing kelompok tersebut modal usaha bersama tentu akan lebih dapat bermanfaat bagi pengembangan hasil ekonomi maupun keahlian ekonomi.

Sekilas, penerapan pendayagunaan zakat produktif sebagai zakat produktif di kalangan sabilillah dan fakir miskin mungkin akan menghasilkan sebuah pertanyaan apakah tidak akan terlalu lama jika harus dibagikan per kelompok? Penerapan zakat produktif di kalangan mustahik zakat dimungkinkan akan memakan waktu lama agar dapat diterima secara menyeluruh oleh kelompok mustahik zakat. Penyebabnya tidak lain adalah adanya dua nilai yang terkandung dalam penerapan zakat produktif pada pendayagunaan zakat produktif. Nilai yang pertama adalah berkaitan dengan upaya untuk meningkatkan perekonomian anggota masing-masing kelompok. Sedangkan nilai yang kedua tidak lain adalah dengan adanya penerapan zakat produktif dalam pendayagunaan zakat produktif, maka secara tidak langsung akan memunculkan muzakki baru. Mustahik yang sebelumnya hanya menerima zakat akan dapat berubah menjadi muzakki yang mengeluarkanzakatdarilabayangdihasilkanmelaluiusahayangdibentukdaripendayagunaanzakat.

Dengan demikian, pendayagunaan zakat secara produktif akan lebih terlihat manfaatnya manakala dilaksanakan secara kolektif. Keuntungan-keuntungan yang ada dalam pelaksanaan pendayagunaan zakat untuk usaha produktif secara kolektif, , antara lain adalah sebagai berikut:

1. Dapat dijadikan sebagai media penguat ukhuwah Islamiyah.

Dengan adanya kerjasama antara beberapa mustahik dalam mengelola usaha produktif dari pendayagunaan zakat produktif akan memperkuat rasa persaudaraan.

2. Mempermudah pengawasan dan pelatihan.

Konsekuensi dari tujuan untuk meningkatkan kualitas hasil ekonomi maupun keahlian

27 Direktorat Pengembangan Zakat dan Wakaf Dirjen Bimas Islam Dan Penyelenggara Haji Depag RI, Pedoman Zakat, 2003. 
ekonomi di kalangan mustahik dalam mengembangkan usaha produktif adalah adanya upaya pengawasan dan pelatihan. Selama ini pendayagunaan zakat produktif untuk usaha produktif cenderung masih hanya berjalan satu arah. Maksudnya adalah setelah zakat didistribusikan sebagai zakat produktif, tidak ada upaya pengawasan maupun pelatihan. Jika hal ini tetap dilakukan, tentu riskan terhadap ketidakmaksimalan atau bahkan kegagalan dalam mendayagunakan zakat produktif untuk usaha produktif. Apabila dilakukan pengawasan secara individu, maka hal tersebut akan membutuhkan dan melibatkan banyak pengawas dan pelatih. Namun jika pendayagunaan zakat produktif untuk usaha produktif dilakukan secara kolektif, maka hal tersebut akan memudahkan proses pengawasan maupun pelatihan. Dengan demikian tujuan untuk mengembangkan hasil maupun keahlian ekonomi yang juga berimbas pada pergantian status dari mustahik menjadi muzakki akan lebih mudah terwujudkan.

3. Akan lebih cepat dalam memunculkan kesadaran dan kemauan untuk berzakat.

Jika pendayagunaan zakat untuk usaha produktif diperuntukkan bagi perorangan, mungkin kesadaran dan kemauan untuk mengeluarkan zakat dari hasil usahanya - jika telah memenuhi nishab - tidak akan mudah muncul. Hal ini bisa jadi karena tidak adanya ikatan atau hubungan antara mustahik zakat dengan LAZIS NU Cabang Kendal. Namun jika pendayagunaan zakat untuk usaha produktif dilakukan secara kolektif, maka akan dapat mendorong mustahik untuk mengeluarkan zakat produktifnya manakala telah memenuhi nishab. Meskipun tanpa adanya hubungan atau ikatan antara mustahik dengan LAZIS NU Cabang Kendal, hal ini bisa terjadi karena secara tidak langsung, dalam pendayagunaan zakat usaha produktif secara kolektif terdapat aspek saling mengingatkan antar mustahik, termasuk mengingatkan konsekuensi dari asal muasal modal usaha yang mereka dapatkan.

4. Memudahkan munculnya muzakki baru dari kalangan mustahik

Pendayagunaan zakat produktif untuk usaha produktif secara kolektif, secara tidak langsung akan dapat memudahkan untuk menciptakan muzakki baru dan mengurangi mustahik zakat.

Dari penjelasan di atas, maka ada beberapa hal yang dapat dijadikan solusi terhadap permasalahan serta hal-hal yang berhubungan dengan pengelolaan zakat di LAZIS NU Cabang Kendal. Solusi-solusi tersebut meliputi solusi eksternal dan internal.

\section{Solusi eksternal}

Solusi eksternal adalah solusi yang berkaitan dengan hubungan LAZIS NU Cabang kendal dengan LAZIS NU yang berada di bawahnya. Solusi ini dapat diwujudkan dengan mengefektifkan hubungan antara LAZIS NU Cabang Kendal dengan LAZIS NU yang berada di bawahnya dan dengan BAZ atau LAZ yang lainnya.

Efektifitas hubungan antara LAZIS NU Cabang Kendal dengan LAZIS NU yang berada di bawahnya maupun dengan BAZ atau LAZ lainnya dapat dilakukan dengan mengadakan komunikasi dan koordinasi tentang materi-materi yang berhubungan dengan klasifikasi mustahik zakat dan koordinasi pembagian prioritas mustahik yang berada di bawahnya maupun BAZ atau LAZ lain. 
Pembahasan mengenai mustahik zakat juga perlu dikomunikasikan dan dikoordinasikan dengan BAZ atau LAZ lain oleh LAZIS NU Cabang Kendal. Hal ini dilakukan untuk menghindari asumsi bahwa ada mustahik yang telah menerima padahal sebenarnya belum menerima. Dengan demikian, nantinya akan diketahui klasifikasi mustahik di BAZ atau LAZ lain sehingga LAZIS NU Cabang Kendal akan lebih dapat memaksimalkan pengklasifikasian mustahik zakat yang berhak menerima pendayagunaan zakat pertanian.

Selain membahas mengenai klasifikasi mustahik, perlu ada koordinasi antara LAZIS NU Cabang Kendal dengan BAZ atau LAZ yang berada di wilayah Kabupaten Kendal. Tujuan koordinasi ini tidak lain adalah untuk lebih mengefektifkan pendayagunaan zakat di Kabupaten Kendal. Suatu contoh misalnya adalah adanya koordinasi mengenai pembagian BAZ yang mendapat bagian untuk memberikan pendayagunaan zakat secara produktif dan konsumtif. Atau contoh lain adalah dapat berupa koordinasi kerjasama terkait dengan pengembangan usaha produktif mustahik zakat antar BAZ atau LAZ. Dengan demikian nantinya diharapkan tidak ada tumpang tindih antar BAZ atau LAZ dalam mendayagunakan zakat, khususnya terkait dengan pemilihan mustahik zakat. Selain itu, koordinasi ini juga dapat membantu mempermudah dan meluaskan jaringan usaha produktif antar mustahik zakat sehingga akan lebih mempercepat dalam mengangkat perekonomian mustahik.

\section{Solusi internal}

Solusi internal merupakan solusi yang berhubungan dengan pembenahan internal di LAZIS NU Cabang Kendal. Solusi-solusi internal ini meliputi hal-hal sebagai berikut:

a. Perencanaan terhadap prioritas mustahik zakat

Meskipun termasuk solusi internal, solusi ini tidak dapat dipisahkan dengan proses koordinasi terkait mustahik zakat dengan BAZ atau LAZ di wilayah Kabupaten Kendal. Berdasarkan hasil koordinasi dengan BAZ atau LAZ yang lain, maka LAZIS NU Cabang Kendal perlu mengadakan rapat terkait dengan perencanaan prioritas mustahik zakat. Hal ini dapat dilakukan dengan melakukan langkah-langkah sebagai berikut:

1) Mengadakan pendataan mustahik zakat di luar mustahik zakat yang telah diurusi oleh BAZ atau LAZ selain LAZIS NU Cabang Kendal. Hal ini dilakukan untuk mengetahui jumlah pasti mustahik zakat yang dapat dipilih untuk menjadi mustahik zakat dari pendayagunaan zakat pertanian. Selain itu, pendataan mustahik zakat juga dapat dijadikan acuan untuk menentukan jumlah mustahik zakat pada periode berikutnya dengan melihat perkembangan mustahik zakat sebelumnya. Dengan adanya pendataan ini, mustahik yang telah berhasil merubah kehidupannya melalui pendayagunaan zakat pertanian secara otomatis akan terdata sehingga akan meminimalisir timbulnya penerimaan alokasi zakat dua kali bagi mustahik yang sama yang telah berhasil.

2) Menentukan skala prioritas; LAZIS NU Cabang Kendal membuat skala prioritas untuk menentukan prioritas mustahik zakat yang berhak menerima pendayagunaan zakat pertanian. Penentuan skala prioritas ini mengandung dua aspek yakni aspek prioritas pendayagunaan zakat pertanian dan aspek prioritas mustahik. 
Aspek pendayagunaan zakat pertanian adalah proses untuk menentukan kecenderungan pendekatan yang akan digunakan dalam pendayagunaan zakat pertanian. Untuk mendukung hal tersebut, LAZIS NU Cabang Kendal dapat mengacu pada program kerja Pemkab Kabupaten Kendal maupun keadaan yang terjadi di lapangan. Acuan kepada program kerja Pemkab Kabupaten Kendal tidak lain digunakan untuk mensinergikan fungsi zakat sebagai ibadah sosial yang dapat menunjang keberhasilan program kerja, khususnya terkait dengan program pengentasan kemiskinan. Sedangkan acuan terhadap keadaan yang terjadi lebih bersifat fleksibel. Misalnya, pendayagunaan zakat pertanian telah ditentukan berdasarkan program kerja Pemkab Kendal, namun pada saat yang bersamaan terjadi bencana alam yang menimpa Kabupaten Kendal, maka pendayagunaan zakat pertanian bisa jadi dapat dialihkan (meskipun tidak seluruhnya) sesuai dengan keadaan yang menimpa masyarakat.

Aspek yang kedua adalah prioritas mustahik. Aspek ini secara otomatis akan mengikuti aspek yang pertama. Contohnya adalah manakala prioritas pendayagunaan zakat pertanian cenderung pada zakat produktif, maka yang menjadi prioritas mustahik adalah mustahik yang memiliki keadaan yang benar-benar layak untuk menerima kesempatan guna memperbaiki dan mengembangkan kondisi perekonomiannya.

b. Membuat blue print tentang pendayagunaan zakat pertanian

Sebuah proses pendayagunaan tidak akan dapat dilepaskan dari perencanaan dasar. Oleh sebab itu, LAZIS NU Cabang Kendal perlu membuat perencanaan dan skema pendayagunaan zakat pertanian secara lengkap dan matang. Hal ini akan bermanfaat untuk memudahkan dalam proses penciptaan pendayagunaan zakat pertanian yang efektif dan efisien. Selama ini pendayagunaan zakat pertanian masih kurang efektif karena masih hanya terbatas pada proses pemberian zakat kepada mustahik tanpa adanya perencanaan dan skema pendayagunaan yang utuh dan menyeluruh baik sebagai usaha perbaikan ekonomi secara sosial dan dapat dirasakan oleh seluruh masyarakat yang berhak menerimanya.

c. Pengawasan dan pelatihan mustahik zakat untuk usaha produktif kolektif.

LAZIS NU Cabang Kendal perlu membuat terobosan dengan mendayagunakan zakat pertanian untuk usaha produktif secara kolektif. Hal ini akan lebih mudah membantu dan memotivasi mustahik dalam upaya perbaikan dan pengembangan ekonomi mereka secara bersama-sama dengan mustahik yang lain. Selain membuat model pendayagunaan zakat produktif secara kolektif, LAZIS NU Cabang Kendal juga harus melakukan pengawasan dan pelatihan kepada mustahik yang melakukan usaha produktif. Pelatihan dan pengawasan terhadap usaha produktif akan lebih dapat menunjang upaya percepatan dalam usaha perbaikan dan pengembangan ekonomi mustahik.

d. Pencatatan Mustahik yang telah berhasil

Hal ini merupakan kelanjutan dari proses ketiga dalam solusi internal. Selama ini, kurang diperhatikan tingkat keberhasilan yang telah dicapai oleh mustahik, khususnya yang menerima zakat produktif. Padahal hal tersebut, sangat penting sebagai upaya perbaikan dan pengembangan ekonomi mustahik. Jadi dengan adanya pencatatan mustahik yang telah berhasil paling tidak 
juga dapat digunakan sebagai acuan perubahan jumlah mustahik sekaligus juga menjadi simbol adanya perubahan status dalam diri mustahik terdahulu yang mana telah berubah menjadi muzakki.

Beberapa hal yang perlu menjadi catatan penting dalam pengelolaan zakat pertanian di LAZIS NU Cabang Kendal adalah berkenaan dengan pengelolaan tidak dilakukan secara memusat di LAZIS NU Cabang Kendal melainkan dilaksanakan oleh masing-masing LAZIS NU di tingkat Pengurus Ranting. Namun demikian, pengelolaan zakat pertanian tersebut tidak dilaksanakan di seluruh LAZIS NU tingkat Pengurus Ranting. Hanya 10 Kepengurusan Ranting yang melaksanakan pengelolaan zakat pertanian. Dalam pelaksanaan zakat pertanian, antar kepengurusan ranting terdapat perbedaan pengelolaannya yang mencakup :

1) Waktu pembayaran, yang hanya dilakukan sekali dalam setahun dan ada juga yang dilakukan setiap kali panen. Pelaksanaan pembayaran sekali dalam setahun juga bukan akumulasi dari hasil panen dalam setahun namun hanya dihitung dari hasil panen yang diperoleh ketika mendekati waktu pembayaran zakat pertanian.

2) Distribusi zakat pertanian, ada yang melakukan dalam bentuk distribusi konsumtif semata dan ada yang mendistribusikan dengan model distribusi konsumtif dan produktif.

Selain terdapat perbedaan dalam hal waktu pembayaran dan distribusi, dalam praktek pengelolaan zakat pertanian di LAZIS NU Cabang Kendal juga terdapat permasalahan yang berhubungan dengan proses pengumpulan yakni dalam aspek nishab dan monitoring masyarakat yang wajib zakat. Terkait dengan nishab, dalam prakteknya, muzakki tidak pernah memberitahukan jumlah nishab yang dimilikinya dan bahkan tidak jarang zakat pertanian yang diserahkan kepada LAZIS NU Cabang Kendal melalui kepengurusan tingkat ranting telah dahulu di-tasharuf-kan sendiri. Permasalahan tersebut akan dapat memunculkan dampak negatif dalam dua aspek, yakni aspek legalitas zakat dan aspek legalitas ke-Islam-an masyarakat.

Dampak negatif dari aspek legalitas zakat disebabkan karena tidak adanya upaya untuk melakukan pengecekan terhadap nishab dari harta yang dikeluarkan zakatnya. Apabila jumlah yang dibayarkan telah atau bahkan melebihi nishab, tentu hal ini tidak akan menjadi masalah. Namun, apabila yang dibayarkan tidak memenuhi nishab atau tidak sesuai dengan nishab, maka hal itu akan menjadikan zakat tidak sah dan secara otomatis akan berdampak pada legalitas keIslam-an orang yang semula ingin berzakat.

Selain dari aspek legalitas zakat, dampak negatif aspek legalitas ke-Islam-an juga dapat datang dari tidak adanya upaya LAZIS NU untuk melakukan monitoring terhadap harta hasil panen masyarakat petani. Dengan tidak adanya monitoring tersebut secara tidak langsung LAZIS NU telah memberikan peluang seorang muslim yang memiliki kemampuan berzakat untuk tidak melaksanakan rukun Islam.

\section{Penutup}

Problematika pengelolaan zakat pertanian di LAZIS NU Cabang Kendal terpusat pada dua permasalahan mendasar, yakni problematika dalam pengelolaan dan problematika dalam 
organisasi. Problematika dalam pengelolaan zakat pertanian terpusat pada aspek pengumpulan dan pendayagunaan. Dalam aspek pengumpulan, idealnya LAZIS NU Cabang Kendal lebih berani dalam mensosialisasikan ketentuan zakat yang sebenarnya termasuk peran LAZIS NU dalam proses pengumpulan zakat pertanian, khususnya yang berhubungan dengan penghitungan nishab dan besaran zakat. Hal ini penting untuk meminimalisir praktek zakat yang tidak sampai pada esensi zakat karena ketidaksesuaian nishab. Sedangkan dalam aspek pendayagunaan zakat pertanian, LAZIS NU Cabang Kendal dapat melakukan perubahan pada distribusi zakat produktif. Perubahan tersebut dilaksanakan dengan membuat konsep zakat produktif kolektif. Dengan adanya konsep tersebut, maka peluang zakat sebagai sarana peningkatan ekonomi masyarakat Islam akan lebih terbuka lebar. Selain itu, dengan adanya distribusi kolektif, akan lebih mudah mengawasi dan memberikan bimbingan pengelolaan usaha sekaligus untuk memperkuat persaudaraan (ukhuwah Islamiyah).

Sedangkan problematika dalam aspek organisasi dapat diselesaikan oleh LAZIS NU Cabang Kendal melalui dua jalan pemecahan, yakni solusi internal dan solusi eksternal. Untuk solusi eksternal, LAZIS NU Cabang Kendal lebih mempererat komunikasi dengan LAZ maupun BAZ lainnya sehingga akan lebih dapat mengetahui peta mustahik. Pengetahuan mengenai peta mustahik tersebut akan lebih mengefektifkan dan mengefisienkan pemberian zakat yang tepat sasaran tanpa adanya kekhawatiran pemberian zakat kepada mustahik yang telah menerima zakat dari LAZ maupun BAZ lainnya. Sedangkan solusi internal dapat dilaksanakan oleh LAZIS NU Cabang Kendal dengan lebih mempererat komunikasi dengan LAZIS-LAZIS NU yang ada di bawahnya. Komunikasi ini akan lebih memudahkan pencapaian tujuan. Hal ini dikarenakan dalam komunikasi ini akan lebih dapat "terbaca" keadaan mustahik di masing-masing wilayah/ daerah. Di samping melakukan komunikasi, solusi internal juga mencakup pembuatan blue print tentang pendayagunaan zakat pertanian, pengawasan dan pelatihan mustahik zakat untuk usaha produktif kolektif, dan pencatatan mustahik yang telah berhasil. 
120 Abdul Hakim 